IZA DP No. 200

What are Migration Networks?

Thomas Bauer

Gil Epstein

Ira N. Gang

September 2000 


\title{
What are Migration Networks?
}

\author{
Thomas Bauer \\ University of Bonn, CEPR, London and IZA, Bonn \\ Gil Epstein \\ Bar Ilan University, Ramat Gan, CEPR, London and IZA, Bonn \\ Ira N. Gang \\ Rutgers University, New Jersey and IZA, Bonn
}

Discussion Paper No. 200

September 2000

\author{
IZA \\ P.O. Box 7240 \\ D-53072 Bonn \\ Germany \\ Tel.: +49-228-3894-0 \\ Fax: +49-228-3894-210 \\ Email: iza@iza.org
}

This Discussion Paper is issued within the framework of IZA's research area Mobility and Flexibility of Labor Markets. Any opinions expressed here are those of the author(s) and not those of the institute. Research disseminated by IZA may include views on policy, but the institute itself takes no institutional policy positions.

The Institute for the Study of Labor (IZA) in Bonn is a local and virtual international research center and a place of communication between science, politics and business. IZA is an independent, nonprofit limited liability company (Gesellschaft mit beschränkter Haftung) supported by the Deutsche Post AG. The center is associated with the University of Bonn and offers a stimulating research environment through its research networks, research support, and visitors and doctoral programs. IZA engages in (i) original and internationally competitive research in all fields of labor economics, (ii) development of policy concepts, and (iii) dissemination of research results and concepts to the interested public. The current research program deals with (1) mobility and flexibility of labor markets, (2) internationalization of labor markets and European integration, (3) the welfare state and labor markets, (4) labor markets in transition, (5) the future of work, (6) project evaluation and (7) general labor economics.

IZA Discussion Papers often represent preliminary work and are circulated to encourage discussion. Citation of such a paper should account for its provisional character. 
IZA Discussion Paper No. 200

September 2000

\section{ABSTRACT \\ What are Migration Networks?*}

Migration networks are usually captured by the number of people from the migrant's country in the host region. Using Mexican migration data, we analyze the effects of the usual network variable and two additional origin-village-specific variables on migrants' location choice.

JEL Classification: F22, J61

Keywords: Location choice, networks, immigration

Thomas Bauer

IZA

P.O. Box 7240

53072 Bonn

Germany

Tel.: +49-228-3894-529

FAX: +49-228-3894-510

Email: bauer@iza.org

\footnotetext{
* We thank Julie Phillips for discussions and helping us with the data. We thank Myeong-Su Yun for his comments. This paper was partly written while Gil Epstein and Ira Gang were visiting IZA, Bonn. Ira Gang thanks the Rutgers Research Council for partial support.
} 


\section{INTRODUCTION}

The prevailing explanation for ethnic clustering is the existence of beneficial network externalities. Migration networks affect migrants' location decisions through three channels. First, they provide information about the host region labor market. Second, migrants' utility increases with the amount of ethnic goods available in a location. Third, migrants expect previous migrants to help them in the settlement process.

In network externalities models, costs of relocation decrease with the number of immigrants, encouraging more emigration, and leading to immigrant clustering (DarvishLecker, 1990; Epstein and Hillman, 1998). It is not straightforward, however, that a larger local network increases the probability of migrating to that location. A migrant's utility is a positive function of both wages and the number of immigrants at a location. However, an increasing number of migrants in a location increases the supply of workers with similar characteristics, and decreases wages as a result of additional competition. As the number of migrants increases, the network externalities effect on utility initially dominates the negative wage effect. Later the negative wage effect will dominate network externalities; increasing the number of immigrants further will decrease the migrant's utility. Overall, an inverse U-shaped relationship between the number of migrants in a location and the probability of moving there will appear. An alternative explanation of such an inverse U-shaped relationship is the possibility that as the number of migrants in a location increases beyond a certain point there will be negative reactions from the local community towards the immigrants.

Empirically, migration networks are usually captured by the number of people from the migrant's country currently in the host region, or by the number of people 
speaking the migrant's native language (Chiswick and Miller, 2000). These variables, however, do not allow us to differentiate the various elements of migration networks.

We examine the location choices of Mexican migrants to the United States. In addition to the usual network variable we include two origin-village-specific effects: the origin-village's total experience in the host region and the total number of origin-village members currently in the host region. The former captures the sum of information including the village's migration history, available to the immigrant. The latter captures current links as well as labor supply effects. By including these two village-specific network measures, the usual network variable captures the effects of the availability of ethnic goods.

\section{DATA}

We estimate conditional logit models to study the location choice of Mexican migrants in the United States (McFadden, 1984). We use individual level data on Mexican-U.S. migration collected by the Mexican Migration Project since $1982 .{ }^{1}$ The data comprises more than 7,000 households in 52 Mexican communities and includes information on the socioeconomic characteristics and the migration history of the household head. The data further allows us to analyze whether there are differences in the location choice of migrants on their first and last trips.

The key variables in our analysis are three measures of migration networks. Similar to other studies, we calculated the share of the total Mexican population in a

1 See Donato, Durant and Massey (1992) and Phillips and Massey (2000) for a description of the data. The data is available at http://www.pop.upenn.edu/mexmig/. 
particular U.S. community $j{ }^{2}$ Second, for each year $t$, we calculated the number of current migrants from the Mexican community $k$ in the U.S. community $j, M_{k j t}$, which gives us our first origin-village-specific measure of migration networks. Third, using the migration duration information provided in an event-history file of the data set, we calculated for each year $t$ the migration duration experience of each migrant $m$ from the Mexican community $k$ in each U.S. location $j, D_{m k j t}$. The cumulative migration experience of a Mexican community in a specific U.S. location at time $t, C M E X P_{k j t}$, is then given by $\quad C M E X P_{k j T}={ }_{t=0}^{T}{ }_{m=1}^{M} D_{m k j t}$ for each $t=0, \ldots, T$ and $m=1, \ldots, M . \quad$ This measure shows the absolute migration experience of a Mexican community in a particular U.S. community in years.

To control for other factors that might affect the utility levels associated with a receiving area, we include the total population and the unemployment rate in an U.S. area. We further include the consumer price index (with the base year 1982-1984) in an U.S. area, to control for the relative the costs of living. We use the driving distance in miles from the place of origin to the destination as a proxy for migration costs.

\section{RESULTS}

Columns two to four of Table 1 present the results for our three network variables (and their squares) on a migrant's first trip to the U.S. The second column includes the standard variable, the share of the Mexican population in a location in the U.S., and its square. Similar to the existing literature (Bartel, 1989; Jaeger, 2000) our results show

\footnotetext{
2 See Phillips and Massey (2000) for the construction of this variable.
} 
that as the size of the network in a location increases, the probability of choosing this location increases. The coefficient on the squared-term indicates that there is an inverse U-shaped relationship. In the third column we have added cumulative migration experience and the number of current migrants, and their squares, to the estimation. The share of the Mexican population and its square maintain their significance and signs, but the size of the coefficients becomes much smaller. From the estimated coefficients one can calculate that the positive effect of the share of the Mexican population in an U.S. location becomes negative when it increases beyond $10 \%$.

Our results show that village-specific effects play an important role in the migrant's location decision: the total effect of networks on a migrant's location choice significantly depends on both the cumulative migration experience of the sending village and the current number of fellows from the home village in an U.S. location. The effect of the cumulative migration experience of a village is U-shaped, becoming positive after 500 years of experience. In our data, on average, the probability of choosing a specific location in the U.S. increases with the total migration experience of a Mexican village in this location, indicating the importance of the provision of information through migration networks. The number of current migrants from a certain village has an inverse U-shaped effect - too many immigrants located at a certain time at the destination decreases the probability of choosing this location (the probability is at a maximum at 24 migrants from a certain community). Such negative size effects could be the result of wage decreases or local population objections.

The effect of network externalities may vary for different types of migrants. For example, illegal migrants may depend more on migration networks than legal migrants. 
Our above results also hold when we differentiate between legal and illegal migrants. Village-specific effects are more important for illegal migrants if compared to their legal counterparts. Our estimation results confirm the expectation that migrants who already have some migration experience in the U.S. are less dependent on the information provided by the migration network. The effect of the cumulative migration experience of a village on the location choice is much smaller for migrants on their last trip if compared to their first trip, whereas the effects of the other network measures on the location choice does not change.

\section{CONCLUSION}

Our empirical results show that the size of a Mexican migration network in an U.S. location has a positive effect on the probability that individuals will immigrate to this location. However, if the size of the migrant population at a certain location is too large, then there are negative size effects and the probability of choosing this location decreases. 


\section{REFERENCES}

Bartel, A.P., 1989, Where Do the New U.S. Immigrants Live?, Journal of Labor Economics 7(4), 371-391.

Chiswick, B.R. and P.W. Miller, 2000, Do Enclaves Matter in Immigrant Adjustment?, manuscript, University of Illinois at Chicago.

Darvish-Lecker, T., 1990, Externalities in Migration, Economics Letters 33(2), 185-191.

Donato, K.M., J. Durand, and D.S. Massey, 1992, Stemming the Tide? Assessing the Deterrent Effects of the Immigration Reform and Control Act, Demography 29(2), 139-157.

Epstein, G.S. and A.L. Hillmann, 1998, Herd Effects and Migration, CEPR Discussion Paper no. 1811, London: CEPR.

Jaeger, D.A., 2000, Local Labor Markets, Admission Categories, and Immigrant Location Choice, mimeo., Hunter College and Graduate School of CUNY, New York and IZA, Bonn.

McFadden, D., 1984, Econometric Analysis of Qualitative Choice Models, in: Z. Griliches and M.D. Intriligator, eds., Handbook of Econometrics, Vol. 2 (NorthHolland, Amsterdam).

Phillips, J.A. and D.S. Massey, 2000, Engines of Immigration: Stocks of Human and Social Capital in Mexico, Social Science Quarterly 81(1), 33-48. 
Table: Conditional Logit Analysis of Location Choice of Mexican Migrants

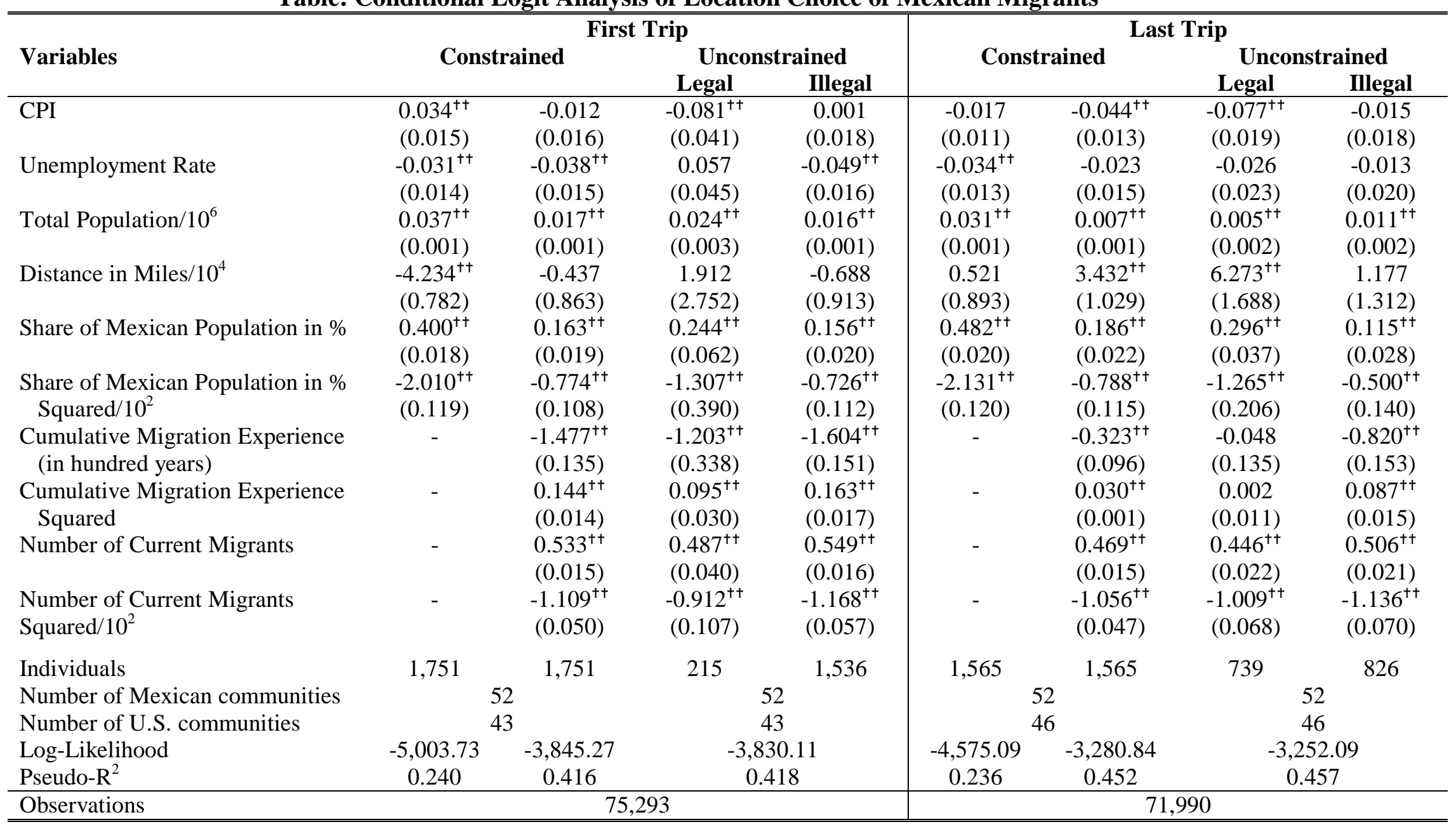

Note: Standard errors in parentheses. ${ }^{\dagger}$ : statistically significant at least at the $10 \%$-level. ${ }^{\dagger+}$ : statistically significant at least at the $5 \%$-level. 


\section{IZA Discussion Papers}

\begin{tabular}{|c|c|c|c|c|}
\hline No. & Author(s) & Title & Area & Date \\
\hline 101 & $\begin{array}{l}\text { L. Husted } \\
\text { H. S. Nielsen } \\
\text { M. Rosholm } \\
\text { N. Smith }\end{array}$ & $\begin{array}{l}\text { Employment and Wage Assimilation of Male First } \\
\text { Generation Immigrants in Denmark }\end{array}$ & 3 & $1 / 00$ \\
\hline 102 & $\begin{array}{l}\text { B. van der Klaauw } \\
\text { J. C. van Ours }\end{array}$ & $\begin{array}{l}\text { Labor Supply and Matching Rates for Welfare } \\
\text { Recipients: An Analysis Using Neighborhood } \\
\text { Characteristics }\end{array}$ & $2 / 3$ & $1 / 00$ \\
\hline 103 & K. Brännäs & $\begin{array}{l}\text { Estimation in a Duration Model for Evaluating } \\
\text { Educational Programs }\end{array}$ & 6 & $1 / 00$ \\
\hline 104 & S. Kohns & $\begin{array}{l}\text { Different Skill Levels and Firing Costs in a } \\
\text { Matching Model with Uncertainty - } \\
\text { An Extension of Mortensen and Pissarides (1994) }\end{array}$ & 1 & $1 / 00$ \\
\hline 105 & $\begin{array}{l}\text { G. Brunello } \\
\text { C. Graziano } \\
\text { B. Parigi }\end{array}$ & $\begin{array}{l}\text { Ownership or Performance: What Determines } \\
\text { Board of Directors' Turnover in Italy? }\end{array}$ & 1 & $1 / 00$ \\
\hline 106 & $\begin{array}{l}\text { L. Bellmann } \\
\text { S. Bender } \\
\text { U. Hornsteiner }\end{array}$ & $\begin{array}{l}\text { Job Tenure of Two Cohorts of Young German Men } \\
1979 \text { - 1990: An analysis of the (West-)German } \\
\text { Employment Statistic Register Sample concerning } \\
\text { multivariate failure times and unobserved } \\
\text { heterogeneity }\end{array}$ & 1 & $1 / 00$ \\
\hline 107 & $\begin{array}{l}\text { J. C. van Ours } \\
\text { G. Ridder }\end{array}$ & $\begin{array}{l}\text { Fast Track or Failure: A Study of the Completion } \\
\text { Rates of Graduate Students in Economics }\end{array}$ & 5 & $1 / 00$ \\
\hline 108 & $\begin{array}{l}\text { J. Boone } \\
\text { J. C. van Ours }\end{array}$ & $\begin{array}{l}\text { Modeling Financial Incentives to Get Unemployed } \\
\text { Back to Work }\end{array}$ & $3 / 6$ & $1 / 00$ \\
\hline 109 & $\begin{array}{l}\text { G. J. van den Berg } \\
\text { B. van der Klaauw }\end{array}$ & $\begin{array}{l}\text { Combining Micro and Macro Unemployment } \\
\text { Duration Data }\end{array}$ & 3 & $1 / 00$ \\
\hline 110 & $\begin{array}{l}\text { D. DeVoretz } \\
\text { C. Werner }\end{array}$ & $\begin{array}{l}\text { A Theory of Social Forces and Immigrant Second } \\
\text { Language Acquisition }\end{array}$ & 1 & $2 / 00$ \\
\hline 111 & $\begin{array}{l}\text { V. Sorm } \\
\text { K. Terrell }\end{array}$ & $\begin{array}{l}\text { Sectoral Restructuring and Labor Mobility: } \\
\text { A Comparative Look at the Czech Republic }\end{array}$ & $1 / 4$ & $2 / 00$ \\
\hline 112 & $\begin{array}{l}\text { L. Bellmann } \\
\text { T. Schank }\end{array}$ & $\begin{array}{l}\text { Innovations, Wages and Demand for } \\
\text { Heterogeneous Labour: New Evidence from a } \\
\text { Matched Employer-Employee Data-Set }\end{array}$ & 5 & $2 / 00$ \\
\hline 113 & R. Euwals & $\begin{array}{l}\text { Do Mandatory Pensions Decrease Household } \\
\text { Savings? Evidence for the Netherlands }\end{array}$ & 3 & $2 / 00$ \\
\hline 114 & $\begin{array}{l}\text { G. Brunello } \\
\text { A. Medio }\end{array}$ & $\begin{array}{l}\text { An Explanation of International Differences in } \\
\text { Education and Workplace Training }\end{array}$ & 2 & $2 / 00$ \\
\hline 115 & $\begin{array}{l}\text { A. Cigno } \\
\text { F. C. Rosati }\end{array}$ & $\begin{array}{l}\text { Why do Indian Children Work, and is it Bad for } \\
\text { Them? }\end{array}$ & 3 & $2 / 00$ \\
\hline
\end{tabular}


117 S. Bender

A. Haas

C. Klose

118 M. A. Shields M. E. Ward

119 A. Lindbeck

D. J. Snower

120 P. T. Pereira

P. S. Martins

121
J. C. van Ours

122

D. Munich

J. Svejnar

K. Terrell

123 J. Hunt

124 R. T. Riphahn

125 F. Büchel

J. R. Frick

126 J. Fersterer

R. Winter-Ebmer

127 M. Karanassou

D. J. Snower

128

O. Ashenfelter

D. Ashmore

O. Deschênes

129 B. R. Chiswick

M. E. Hurst

130
G. Brunello
S. Comi
C. Lucifora

131 B. R. Chiswick

R. A. Hart

133

IAB Employment Subsample 1975-1995.

Opportunities for Analysis Provided by the

Anonymised Subsample

Improving Nurse Retention in the British National

Health Service: The Impact of Job Satisfaction on

Intentions to Quit

The Division of Labor and the Market for

Organizations

Does Education Reduce Wage Inequality?

Quantile Regressions Evidence from Fifteen

European Countries

Do Active Labor Market Policies Help Unemployed 4/6 3/00

Workers to Find and Keep Regular Jobs?

Returns to Human Capital under the Communist

Wage Grid and During the Transition to a Market

5

$2 / 00$

Economy

Why Do People Still Live in East Germany?

Rational Poverty or Poor Rationality? The Take-up 3

The Income Portfolio of Immigrants in Germany -

Who Gains from Income Re-Distribution?

Smoking, Discount Rates, and Returns to

Education

Characteristics of Unemployment Dynamics: The

Chain Reaction Approach

Do Unemployment Insurance Recipients Actively

Seek Work? Evidence From Randomized Trials in

Four U.S. States

The Employment, Unemployment and

Unemployment Compensation Benefits of

Immigrants

The Returns to Education in Italy: A New Look at the Evidence

Are Immigrants Favorably Self-Selected? An

Economic Analysis

Hours and Wages in the Depression: British $7 \quad 3 / 00$ Engineering, 1926-1938

Paid and Unpaid Overtime Working in Germany and 1

R. A. Hart

O. Hübler the UK 
134 A. D. Kugler

G. Saint-Paul

135 A. Barrett

P. J. O'Connell

136 M. Bräuninger

M. Pannenberg

137 J.-St. Pischke

138 J. Zweimüller

R. Winter-Ebmer

139 R. A. Hart

Y. Ma

140 G. Brunello

S. Comi

141 R. Hujer

M. Wellner

142 J. J. Dolado

F. Felgueroso

J. F. Jimeno

143 P. J. Luke

M. E. Schaffer

144 G. Saint-Paul

145 M.-S. Yun

146 T. K. Bauer

J. P. Haisken-DeNew

147 M. Belot

J. C. van Ours

148 L. Goerke

149 R. Lalive

J. C. van Ours

J. Zweimüller

150 J. DiNardo

K. F. Hallock

J.-St. Pischke

151 M. Ward
Hiring and Firing Costs, Adverse Selection and

Long-term Unemployment

Is There a Wage Premium for Returning Irish

Migrants?

Unemployment and Productivity Growth: An

Empirical Analysis within the Augmented Solow Model

Continuous Training in Germany

$3 / 00$

Firm-specific Training: Consequences for Job Mobility

Wages, Hours and Human Capital over the

Life Cycle

Education and Earnings Growth: Evidence from 11

European Countries

The Effects of Public Sector Sponsored Training on Individual Employment Performance in East Germany

Explaining Youth Labor Market Problems in Spain: 3 Crowding-Out, Institutions, or Technology Shifts?

$4 / 00$

Wage Determination in Russia: An Econometric Investigation

Flexibility vs. Rigidity: Does Spain have the worst of 1 both Worlds?

Decomposition Analysis for a Binary Choice Model 7

$4 / 00$

Employer Learning and the Returns to Schooling

5

$4 / 00$

Does the Recent Success of Some OECD

Countries in Lowering their Unemployment Rates

Lie in the Clever Design of their Labour Market

Reforms?

Employment Effects of Labour Taxation in an Efficiency Wage Model with Alternative Budget Constraints and Time Horizons

The Impact of Active Labor Market Programs and Benefit Entitlement Rules on the Duration of Unemployment

Unions and the Labor Market for Managers 
J. F. Jimeno

153 A. S. Kalwij

M. Gregory

154 M. Gerfin

M. Lechner

155 J. Hansen

156 C. Dustmann

F. Fabbri

157 P. Apps

R. Rees

158 A. Björklund

T. Eriksson

M. Jäntti

O. Raaum

E. Österbacka

159 P.- J. Jost

M. Kräkel

160 M. Lofstrom

161 V. Gimpelson

D. Treisman

G. Monusova

162 C. Dustmann

M. E. Rochina-

Barrachina

163 R. A. Hart

Y. Ma

164 M. A. Shields

S. Wheatley Price

165

P. J. Pedersen

166 Z. MacDonald

M. A. Shields

167 A. Barrett

J. FitzGerald

B. Nolan

168 G. S. Epstein

A. L. Hillman
State: An Appraisal

Overtime Hours in Great Britain over the Period 3

1975-1999: A Panel Data Analysis

Microeconometric Evaluation of the Active Labour 6

$5 / 00$

Market Policy in Switzerland

The Duration of Immigrants' Unemployment Spells: $\quad 1 / 3$

Evidence from Sweden

Language Proficiency and Labour Market Per- 1

formance of Immigrants in the UK

Household Production, Full Consumption and $\quad 7$

the Costs of Children

Brother Correlations in Earnings in Denmark, 5

Finland, Norway and Sweden Compared to the

United States

Preemptive Behavior in Sequential Tournaments

5

$5 / 00$

A Comparison of the Human Capital and Signaling Models: The Case of the Self-Employed and the 5 Increase in the Schooling Premium in the 1980's

Public Employment and Redistributive Politics: 4 Evidence from Russia's Regions

Selection Correction in Panel Data Models: An 6 Application to Labour Supply and Wages

Why do Firms Pay an Overtime Premium?

5

$6 / 00$

Racial Harassment, Job Satisfaction and Intentions

5

$6 / 00$ to Quit:

Immigration in a High Unemployment Economy: 1 The Recent Danish Experience

The Impact of Alcohol Consumption on Occupa- 5 tional Attainment in England

Earnings Inequality, Returns to Education and 5 Immigration into Ireland

Social Harmony at the Boundaries of the Welfare 3 State: Immigrants and Social Transfers 
Wages and the Demand for Health - A Life Cycle Analysis

Reforming the Financial Incentives of the Welfare

Self-Employment and Earnings among High-

Skilled Immigrants in the United States

Industrial Relations and the Wage Differentials

between Skilled and Unskilled Blue-Collar

Workers within Establishments: An Empirical

Analysis with Data of Manufacturing Firms

Immigrant Adjustment in Israel: Literacy and

178 R. Euwals M. Ward

179 E. Wasmer

P. Weil

Fluency in Hebrew and Earnings

The Renumeration of British Academics

The Macroeconomics of Labor and Credit Market Imperfections

180 T. K. Bauer

I. N. Gang

Sibling Rivalry in Educational Attainment: 
A. S. Kalwij

A. Zaidi

193 A. Kunze

Absolute Risk Aversion and the Returns to Education

The Determination of Wages and the Gender Wage Gap: A Survey

194 A. Newell

198 M. Kreyenfeld

A Forgotten Issue: Distributional Effects of Day

3 